\title{
Mineral Resources of the Pit River Canyon Wilderness Study Area, Lassen County, California
}

\section{U.S. GEOLOGICAL SURVEY BULLETIN 1706-E}

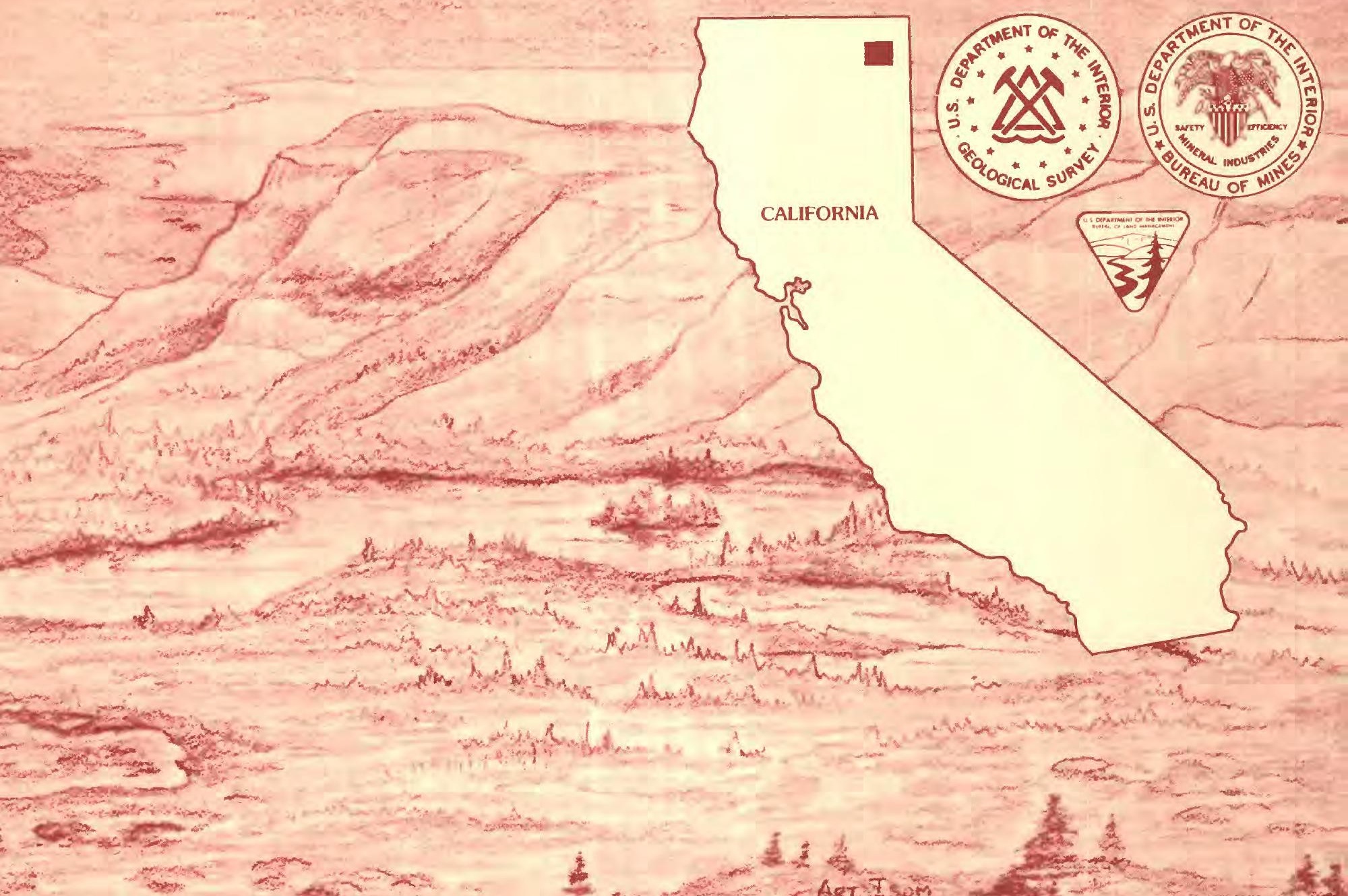


Chapter E

MINERAL RESOURCES OF WILDERNESS STUDY AREAS: NORTHEASTERN

CALIFORNIA AND PART OF ADJACENT WASHOE COUNTY, NEVADA

\section{Mineral Resources of the Pit River Canyon Wilderness Study Area, Lassen County, California}

BY MAUREEN G. SHERLOCK

U.S. Geological Survey

HARRY W. CAMPBELL

U.S. Bureau of Mines 


\section{DEPARTMENT OF THE INTERIOR \\ DONALD PAUL HODEL, Secretary \\ U.S. GEOLOGICAL SURVEY \\ Dallas L. Peck, Director}

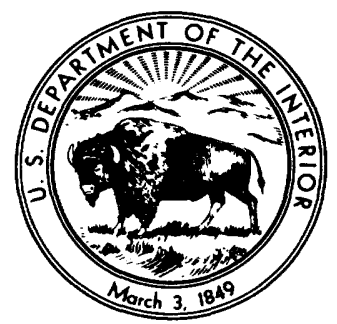

UNITED STATES GOVERNMENT PRINTING OFFICE : 1986

For sale by the

Distribution Branch, Text Products Section

U.S. Geological Survey

604 South Pickett St.

Alexandria, VA 22304

Sherlock, Maureen G.

Mineral resources of the Pit River Canyon

Wilderness Study Area, Lassen County, California

(U.S. Geological Survey Bulletin; B1706-E

Bibliography: p.

Supt. of Docs. no.: । 19.3:1706-E

1. Mines and mineral resources-California-Pit

River Canyon Wilderness. 2. Geology-California-

Pit River Canyon Wilderness. 3. Pit River Canyon

Wilderness (Calif.) I. Campbell, Harry W. II. Title.

III. Series: Geological Survey Bulletin; B1706-E.

$85-600343$ 


\section{STUDIES RELATED TO WILDERNESS}

\section{Bureau of Land Management Wilderness Study Areas}

The Federal Land Policy and Management Act (Public Law 94-579, October 21, 1976) requires the U.S. Geological Survey and the U.S. Bureau of Mines to conduct mineral surveys on certain areas to determine the mineral values, if any, that may be present. Results must be made available to the public and be submitted to the President and the Congress. This report presents the results of a mineral survey of the Pit River Canyon Wilderness Study Area (CA-020-103), Lassen County, California. 


\section{CONTENTS}

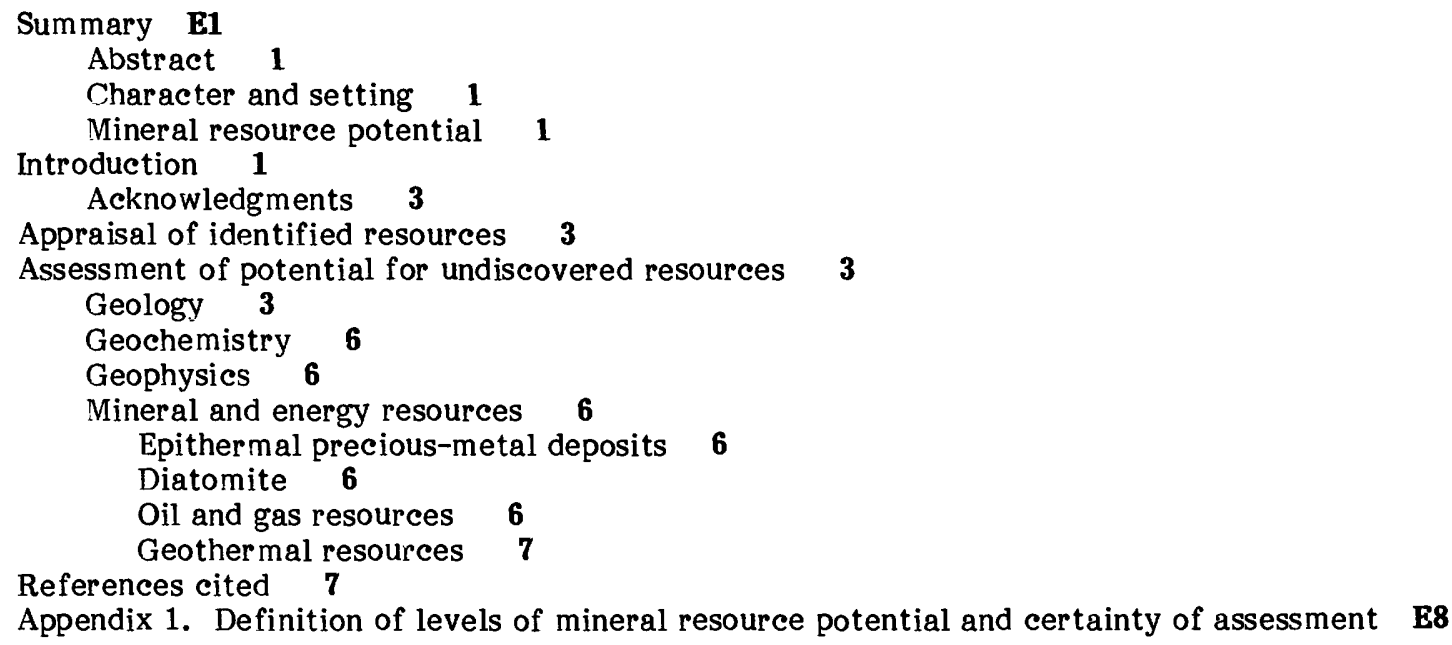

\section{FIGURES}

1. Index map showing the location of the Pit River Canyon Wilderness Study Area, Lassen County, California E2

2. Map showing mineral resource potential of the Pit River Canyon Wilderness Study Area, Lassen County, California 4

3. Major elements of mineral resource potential/certainty classification. 8 


\title{
Mineral Resources of the Pit River Canyon
}

\section{Wilderness Study Area, Lassen County, California}

\author{
By Maureen G. Sherlock \\ U.S. Geological Survey \\ and Harry W. Campbell \\ U.S. Bureau of Mines
}

\section{SUMMARY}

\begin{abstract}
The Pit River Canyon Wilderness Study Area (CA-020-103) includes 5,400 acres along the Pit River and its tributary Horse Creek in Lassen County, northeastern California. The U.S. Geological Survey and the U.S. Bureau of Mines examined the area and took stream sediment and rock samples during May and June 1984. No mines or prospects are located in the area; rock types that host metal deposits are absent. A cinder cone on which cinders were mined from a pit $0.3 \mathrm{mi}$ west of the study area does not extend into the area. Basalt suitable for aggregate and fill crops out in the wilderness study area, but the same kind of rock is abundant closer to potential markets. There is a low mineral resource potential in the area for gold, silver, diatomite, oil and gas, and geothermal energy. The certainty level of the mineral resource assessment is C.
\end{abstract}

\section{Character and Setting}

The Pit River Canyon Wilderness Study Area is about $22 \mathrm{mi}$ east-northeast of Burney, California (fig. 1), and about $30 \mathrm{mi}$ north-northeast of Lassen Volcanic National Park, in the northeastern part of the state. Plateau topography characterizes the region, although the study area encloses the deep canyons of the Pit River and Horse Creek. The Pit River Canyon is as deep as $750 \mathrm{ft}$ and Horse Creek Canyon is about $400 \mathrm{ft}$ deep. The only bedrock unit that crops out in the study area is Tertiary basalt (fig. 2).

\section{Mineral Resource Potential}

The Pit River Canyon Wilderness Study Area contains no identified mineral resources. See figure 2 for an assessment of mineral resource potential.
Available information from geochemical anaylsis of stream-sediment samples does not show anomalous concentrations of any element indicative of mineralized rock in the drainage area, and existing geophysical surveys show anomalies typical of continental basaltic terrane. Mineral resources near the study area include volcanic cinders, diatomite, gold, silver, sand, gravel, and stone. Basalt from the study area could be used as aggregate and fill, but other suitable rock is available closer to potential markets. The sand and gravel deposits in the area are small and access to them is generally poor; sand and gravel deposits are also plentiful closer to potential markets. No metallic or industrial minerals were found during this study.

\section{INTRODUCTION}

The Pit River Canyon Wilderness Study Area (CA-020-103) covers 5,400 acres in Lassen County, nor theastern California. It includes about 11 linear mi of the steep, narrow canyon of the Pit River, where elevations range from 3,400 to $4,000 \mathrm{ft}$ at the bottom of the canyon and from 3,800 to $4,400 \mathrm{ft}$ along the canyon rim. The canyon is 200 to $750 \mathrm{ft}$ deep. The highest peak within the study area is 4,539 ft at First Butte (fig. 2). Four-wheel drive roads and trails that cross the plateau provide access to the canyon rim. The canyon bottom in the study area is relatively inaccessible. In places it is choked by talus composed of large boulders and there are no maintained trails into the canyon. Pit River and Horse Creek are perennial; North and Spring gulches at the northeast boundary and other gulches are intermittent streams. All other gulches or canyon entrants are dry.

Dense vegetation along the canyon walls and rims consists of ponderosa and jeffrey pine, juniper, oak, mahogany, and numerous shrubs and grasses. Grasses, willow, and numerous hydrophilic plants grow abundantly along the creek bottoms. Golden eagles and prairie falcons nest in the canyon. 


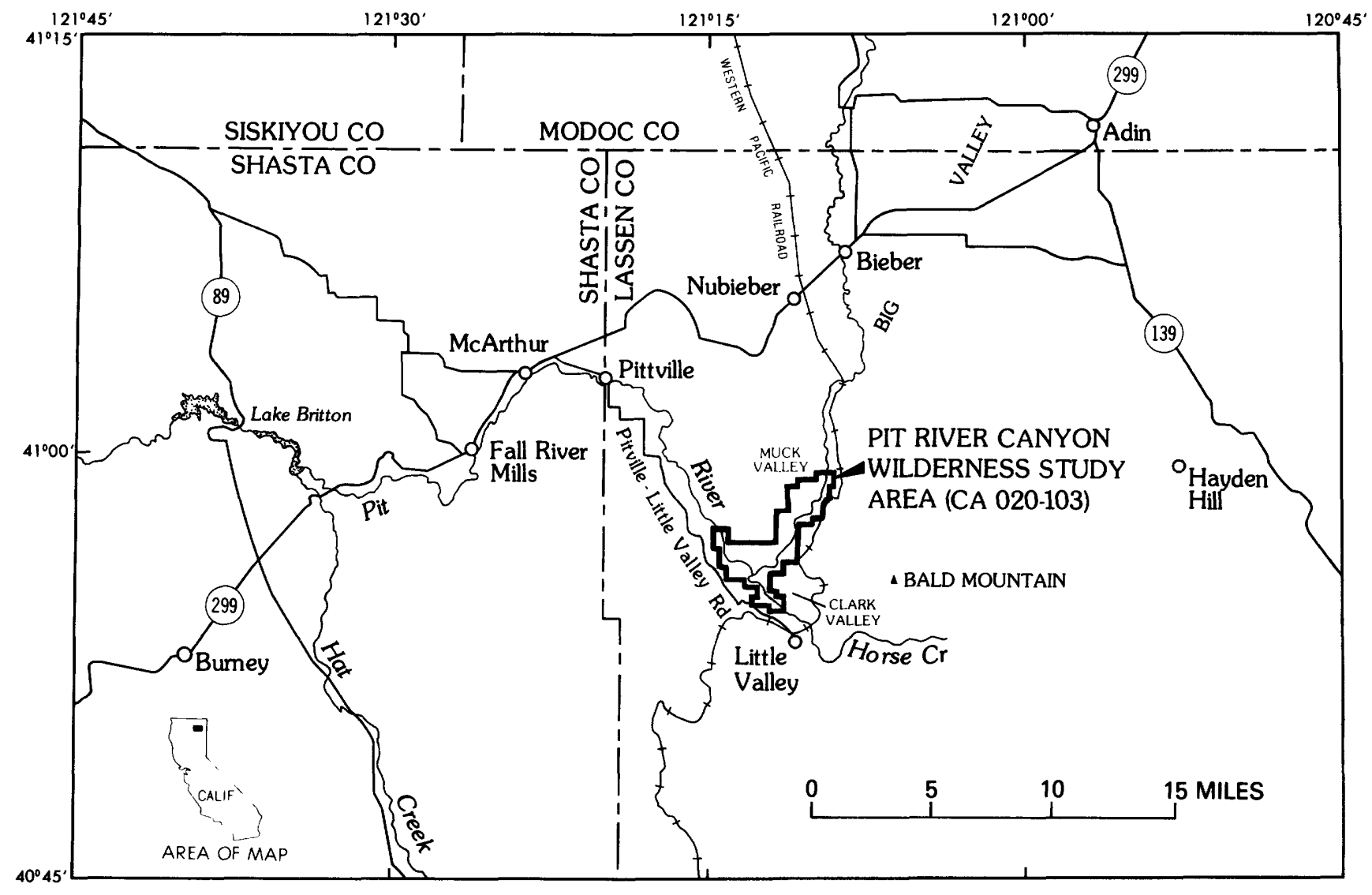

Figure 1. Index map showing the location of the Pit River Canyon Wilderness Study Area, Lassen County, California 
The Pit River Canyon Wilderness Study Area is about $22 \mathrm{mi}$ east-northeast of Burney, and is about 10 mi south of State Highway 299 between McArthur and Nubieber (fig. 1). Access to Horse Creek and the southern rim of the Pit River canyon is by paved road from California State Highway 299 from McArthur through Pittville to Little Valley. Dirt roads that lead north from Little Valley through Clark Valley provide access to the south rim of the canyon. Jeep trails that lead east from the Pittville-Little Valley road provide access to the west canyon rim of Horse Creek. The north rim of the Pit River canyon is accessible by dirt roads that lead south from California State Highway 299. The Little Valley 15-minute quadrangle map shows some of these roads and trails (fig. 2). Most unpaved roads become impassable after rain or snow storms. The Western Pacific (now Union Pacific) Railroad crosses the plateau south of the Pit River canyon and forms a small part of the south boundary of the study area; several roads that once crossed the railroad tracks are now blocked.

For this study the U.S. Bureau of Mines searched the literature for evidence of past or present mining activity within and near the study area. Two days of field work in May 1984 consisted of visually examining the study area.

The U.S. Geological Survey mapped the wilderness study area in 1982 at a scale of $1: 62,500$ by photogeologic reconnaissance as part of a study of the Neogene volcanic rocks of the Cascade Range (J.G. Smith, written commun., 1985) and collected eight stream-sediment samples in June 1984. The only prior geologic study of the area has been reconnaissance mapping (Lydon and others, 1960). The two studies assigned different ages to the basalt: Lydon andothers (1960) assigned the basalt a Pleistocene age, but Smith (J.G. Smith, written commun., 1985) believes they are Miocene and Pliocene because of their extension into areas where the rocks have been dated at 2 to $7 \mathrm{~m} . \mathrm{y}$.

\section{Acknowledgments}

The U.S. Bureau of Land Management offices in Alturas and Susanville, Calif., generously provided information about history, vegetation, and road access in the wilderness study area. Land owners in Clark Valley and the Pit River valley kindly allowed passage through their property to the southeast and northeast parts of the study area, respectively. Eugenia Zorich was the field assistant for the U.S. Geological Survey. Lucia Kuizon, geologist, Western Field Operations Center, helped the U.S. Bureau of Mines author with the field work.

\section{APPRAISAL OF IDENTIFIED RESOURCES}

\section{By Harry W. Campbell, U.S. Bureau of Mines}

No mining claims or leases were located within the Pit River Canyon Wilderness Study Area in 1984, and no evidence of previous mining activity was found. Two placer claims, reportedly located north of the study area in the NE $1 / 4$ and NW $1 / 4$, sec. $13, T .36$
N., R. 6 E. (U.S. Bureau of Land Management, 1984), could not be found. This area is underlain by basalt and there is no evidence of valuable minerals.

Cinder pits west and south of the study area consist mostly of red, basaltic cinders and minor lapilli and bombs; irregular stringers of basalt cut the cinders locally. The nearest cinder pit lies $0.3 \mathrm{mi}$ west of the study area boundary (fig. 2). The cinders are used as highway fill and aggregate, and a small plant at Pittville manufactures and sells cinder blocks and other cinder products. The cinder deposits do not extend into the study area.

Basalt from the study area could be used as aggregate and fill, but other suitable rock is available closer to potential markets. Sand and gravel deposits in the study area are small and access to them is generally poor.

\section{ASSESSMENT OF POTENTIAL FOR UNDISCOVERED RESOURCES}

By Maureen G. Sherlock, U.S. Geological Survey

\section{Geology}

The Pit River Canyon Wilderness Study Area lies in the western part of the Modoc Plateau geomorphic province, which consists of a series of north-trending, block-faulted ranges composed of flood basalt, above which rise small shield volcanoes, composite andesitic cones, and cinder cones. Volcanic flows, lakebeds, and alluvium fill intervening basins. The Modoc Plateau is part of the Basin and Range province which was flooded by volcanic flows of the Cascade volcanic province (Macdonald, 1966).

Late Miocene and Pliocene basalt flows ( 2 to 7 m.y., J.G. Smith, written commun., 1985) underlie the study area. They are vesicular to nonvesicular black flows and are commonly 2 to $50 \mathrm{ft}$ thick (Macdonald, 1966). A series of northwest-trending, high-angle normal faults cut the flows. Red soils, which are deepest on flat to gently dipping surfaces, cover much of the plateau; these soils are derived from deeply weathered basalt and contain subrounded boulders.

Neogene andesite of the same age as the basalt formed a shield volcano on Bald Mountain, about $5 \mathrm{mi}$ southeast of the study area. Flows originating from this volcano extend to within $0.25 \mathrm{mi}$ of the study area (fig. 2).

Although basaltic and andesitic flows dominate, lake beds and ash-flow tuffs are exposed locally. Colluvium, formed from the weathering of lava flows, commonly covers these less-resistant rocks. Neither lake beds nor ash-flow tuffs extend into the study area.

Cinder cones are common in the region, but rocks of that age $(120,000$ to 730,000 B.P.; J.G. Smith, written commun., 1985) do not extend into the study area.

An 8 m.y.-old Tertiary dacite complex, composed of ash-flow tuffs, ash beds, and glassy domes (J.G. Smith, written commun., 1985; Finn and Buchanan, 1984), occurs in the Hayden Hill mining district, $12 \mathrm{mi}$ east of the study area. There, argentiferous gold, 


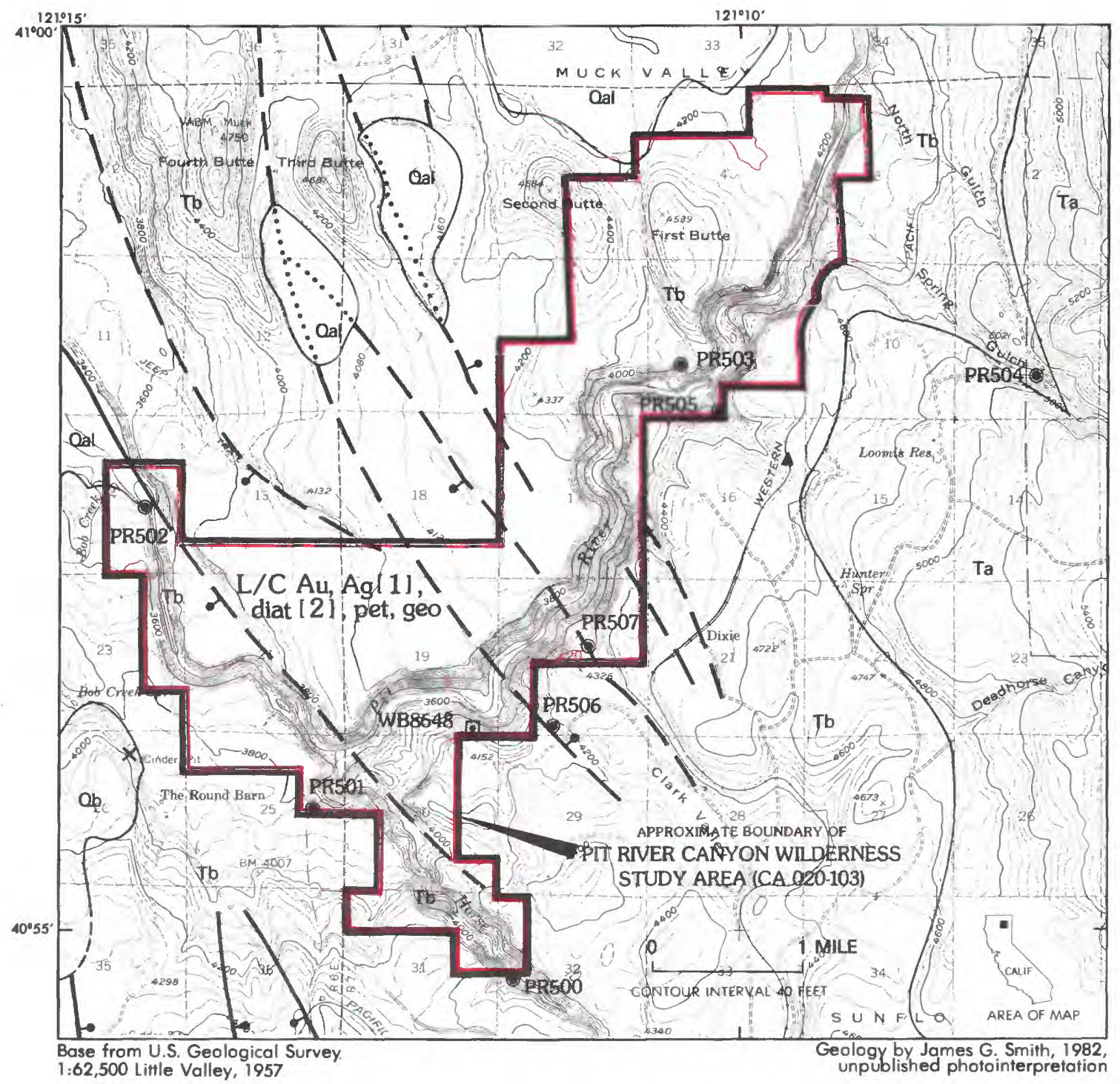

Figure 2. Map showing mineral resource potential of the Pit River Canyon Wilderness Study Area, Lassen County, California 
Area with low mineral or geothermal energy resource potential, certainty level $\mathrm{C}(\mathrm{L} / \mathrm{C})$. Applies to entire wildemess study area. See Appendix 1 and Figure 3 for definition of levels of mineral resource potential and certainty of assesment

\section{COMMODITIES \\ Au Gold \\ Ag Silver \\ Diat Diatomite \\ Pet Oil and gas \\ Geo Geothermal}

\section{[ ] TYPES OF DEPOSITS AND OCCURENCES}

1 Epithermal precious-metal deposits in dacite volcanic rocks

2 Diatomite deposits in lake-bed sediments

\section{CORRELATION OF MAP UNITS}

\begin{tabular}{|l|}
\hline $\mathrm{Qal}$ \\
\hline $\mathrm{Qb}$ \\
\hline
\end{tabular} Quatemary

$\left.\begin{array}{|l|l|}\hline \mathrm{Tb} & \mathrm{Ta}\end{array}\right\}$ Tertiary

GEOLOGIC MAP UNITS

Qal ALLUVIUM (HOLOCENE AND PLEISTOCENE)

Qb BASALT (QUATERNARY)

Tb BASALT (PLIOCENE AND MIOCENE)

Ta ANDESITE (PLIOCENE AND MIOCENE)

\section{MAP SYMBOLS}

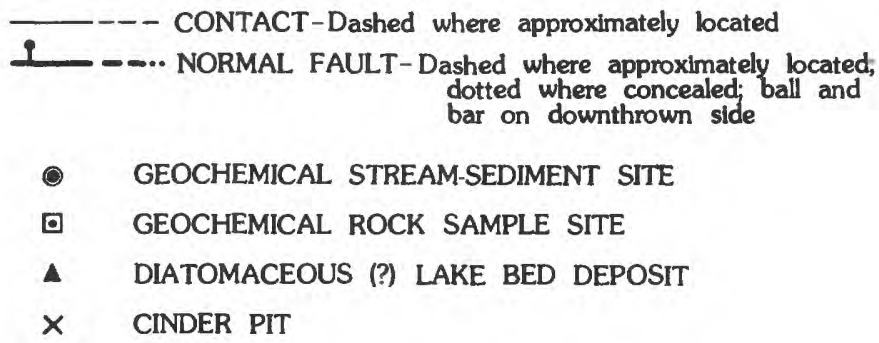

Figure 2.--Continued 
minor silver sulfides, and silver-bearing manganese oxides are disseminated in sulfide-rich breccias, stockworks, and quartz-adularia veins (Finn and Buchanan, 1984). This is the closest mining district to the study area within the Modoc Plateau (Albers and Fraticelli, 1985). No evidence suggests that similar mineralized rocks occur in the study area.

\section{Geochemistry}

Data from eight stream-sediment samples collected in and near the study area (fig. 2) were used to assess the geochemical characteristics and potential of the area. Sediment in seven of the samples was derived totally from basalt. Andesite contributed much of the sediment for sample PR-504. Sampling sites were selected for the availability of stream sediment, potential for panning onsite, and access. Stream sediments in basaltic terranes such as that of the study area typically consist of coarse pebbles and finer material that contains mostly heavy minerals. Consequently, the amount of stream sediment available at a sampling site is commonly small and only a small amount of the light fraction is lost in panning.

Stream-sediment samples and panned concentrates were analyzed by semiquantitative emission spectrography and flame atomic absorption (Sherlock and others, 1985). A representative basalt sample (fig. 2) was analyzed by fire assay-inductively coupled plasma-emission spectrometry methods for gold and silver and forty elements. The results of this U.S. Bureau of Mines sample analysis are included in Sherlock and others (1985). The data indicate an unmineralized volcanic terrane (J.G. Frisken, oral commun., 1985).

\section{Geophysics}

The geophysical evaluation of the study area relied on existing gravity surveys (Oliver and others, 1980). Gravity contours show no anomalous features and are consistent with the volcanic nature of the region. Airborne Gamma-ray spectrometer and magnetometer surveys of the Susanville $1^{\circ}$ by $2^{\circ}$ quadrangle (Western Geophysical Company of America, 1981) also show no anomalies in the study area. There is a thorium anomaly about $5 \mathrm{mi}$ west of the southwest boundary of the study area. This represents an irregular increase in thorium over a large area due to an elevation of background levels rather than to potentially economic deposits (Western Geophysical Company of America, 1981).

\section{Mineral and Energy Resources}

The Modoc Plateau contains few economic mineral deposits. The nearest metallic mineral deposits are in dacite at Hayden Hill, $12 \mathrm{mi}$ to the east; the nearest non-metallic deposits are cinders in Pleistocene basalt $0.3 \mathrm{mi}$ to the west, and diatomite in Pliocene lake beds $17 \mathrm{mi}$ to the west.
Epithermal precious-metal deposits

The Hayden Hill mining district was established (originally as Providence City) after the 1870 discovery of gold in the bottom of a spring which issued from one of the gold- and silver-bearing veins in breccias and silicified felsic tuffs at the base of Hayden Hill (Hill, 1915). Soil covering most of the hill was panned and sluiced for free gold; the highestgrade lode ore was found in manganese-oxide-rich breccias that contain little quartz and sulfides (Hill, 1915). The small lode deposits produced about $\$ 3$ million worth of gold (Clark, 1970). The district is now being explored for large, low-grade disseminated-gold deposits (Clark, 1985). Recent studies (Finn and Buchanan, 1984) indicate three stages of mineralization: brecciation, calcite veining, and quartz-adularia veining. The volcanic sequence at Hayden Hill may be a hot spring vent area (Buchanan, 1983) or part of a caldera (Hazlett and Grose, 1983). Finn and Buchanan (1984) conclude from fluid inclusion studies of the vein minerals that the temperature of formation of these volcanic rocks was $260^{\circ} \mathrm{C}$, indicating that they formed at depths greater than $1,500 \mathrm{ft}$ rather than in hot springs. The dacitic rocks are probably restric ted to the Hayden Hill area (fig. 1) and do not occur in the study area. They are, however, older than the basalt in the Pit River canyon (8.3+0.4 m.y.; Finn and Buchanan, 1984) and could be covered by basalts; but nothing suggests that this is likely. Therefore, the Pit River Canyon Wilderness Study Area has a low potential for epithermal precious-metal ( $\mathrm{Au}, \mathrm{Ag}$ ) deposits with a $\mathrm{C}$ certainty. See Appendix 1 and figure 3 for definitions of levels of mineral resource potential and certainty of assessment.

\section{Diatomite}

Pliocene fresh-water lakebed sediments are being mined for diatomite near Lake Britton and the Hat Creek-Pit River confluence (fig. 1; Oakeshott, 1957; Lydon and O'Brien, 1974). These deposits may have formed in a large lake ponded by lava flows or a large landslide about $2 \mathrm{~m} . \mathrm{y}$. ago (J.G. Smith, oral commun., 1985). Because the elevation of this lake was lower than elevations in the Pit River canyon, the lake probably never extended into the study area. Extensive Pliocene lakebed sediments do not occur within the Pit River Canyon Wilderness Study Area. White, presumably diatomaceous, lakebed sediments, older than those just discussed (J.G. Smith, oral commun., 1985), are exposed in one railroad cut (fig. 2); no interbedded sediments were observed in the study area. The Pit River Canyon Wilderness Study Area has a low potential for diatomite with a $\mathrm{C}$ certainty.

\section{Oil and Gas Resources}

Scott (1983) qualitatively assessed the Modoc Plateau as having a zero to low potential for petroleum. He based this assessment on the known thickness of Cenozoic volcanic rocks that cover marine Cretaceous rocks and scattered Tertiary lake 
beds which could be reservoirs for hydrocarbons. The Pit River Canyon Wilderness Study Area has a low potential for oil and gas resources with a $\mathrm{C}$ certainty.

\section{Geothermal Resources}

Warm-temperature thermal springs occur $3 \mathrm{mi}$ nor thwest of the study area along a northwest-trending fault between basalt and alluvium east of the Pit River (Higgins, 1980). They are the only thermal springs near the study area, but they are not included in the assessment of low-temperature geothermal resources of the United States (Reed, ed., 1983; Reed and others, 1983). The potential for geothermal resources within the Pit River Canyon Wilderness Study Area is low with a C certainty.

\section{REFERENCES CITED}

Albers, J.P., and Fraticelli, L.A., 1985, Preliminary mineral resource assessment map of California: U.S. Geological Survey Mineral Investigations Map MR-88, scale 1:1,000,000.

Buchanan, L.J., 1983, Geology and ore deposits of Hayden Hill, Lassen County, California: Geological Society of America Abstracts with Programs, v. 15, no. 5 , p. 326.

Clark, W. B., 1970, Gold districts of California: California Division of Mines and Geology Bulletin 193 , p. 177.

1985, Gold districts of California-an update: California Geology, v. 48, no. 1, p. 3-4.

Finn, D.R., and Buchanan, L.J., 1984, Hayden Hill, California: Epithermal $\mathrm{Au}-\mathrm{Ag}$ mineralization associated with Cascade volcanism: Geological Society of America Abstracts with Programs, v. 16, no. 6, p. 509.

Hazlett, D.P., and Grose, T.L.T., 1983, The Hayden Hill volcanic center, northeastern California: Geological Society of America Abstracts with Programs, v. 15, no. 5, p. 330.

Higgins, C.T., 1980, Geothermal resources of California: California Division of Mines and Geology, California Geologic Data Map Series Map 4 , scale $1: 500,000$.

Hill, J.M., 1915, Some mining districts in California and Nevada: U.S. Geological Survey Bulletin 594,
$200 \mathrm{p}$.

Lydon, P.A., Gay, T.E., Jr., and Jennings, C.W., 1960, Geologic map of California--Westwood (Susanville) sheet: California Division of Mines and Geology, scale $1: 250,000$.

Lydon, P.A., and O'Brien, J.C., 1974, Mines and Mineral Resources of Shasta County, California: California Division of Mines and Geology County Report 6, 154 p.

Macdonald, G.A., 1966, Geology of the Cascade Range and Modoc Plateau in Bailey, E. H., ed., Geology of northern California: California Division of Mines and Geology Bulletin 190, p. 65-96.

Oakeshott, G.B., 1957, Diatomite, in Wright, L.A., ed., Mineral Resources of California: California Division of Mines and Geology Bulletin 176, p. 183-193.

Oliver, H.W., Robins, S.L., and Griscom, Andrew, 1980, Bouger gravity map of California, Westwood (Susanville) sheet: California Division of Mines and Geology, scale 1:250,000.

Reed, M.J., ed., 1983, Assessment of low-temperature geothermal resources of the United States--1982: U.S. Geological Survey Circular 892, 73 p.

Reed, M.J., Mariner, R.H., Brook, C.A., and Sorey, M.L., 1983, Selected data for low-temperature (less than $90^{\circ}$ C) geothermal systems in the United States: Reference data for U.S. Geological Survey Circular 892: U.S. Geological Survey Open File Report 83-250, $129 \mathrm{p}$.

Scott, E.W., 1983, Petroleum potential of wilderness lands in California: U.S. Geological Survey Miscellaneous Geologic Investigations Map I-538, scale $1: 1,000,000$.

Sherlock, M.G., Frisken, J.G., Adrian Betty, Zorich, Eugenia, 1985, Geochemical analyses of streamsediment samples from the Pit River Canyon Wilderness Study Area, Lassen County, California: U.S. Geological Survey Open-File Report 85-390, $12 \mathrm{p}$.

U.S. Bureau of Land Management, 1984, Geographic index for California: Mining Claim Recordation Index, March 1984.

Western Geophysical Company of America, 1981, National Uranium Resource Evaluation Program, airborne gamma-ray spectrometer and magnetometer survey, Susanville quadrangle, California: Grand Junction, Colo., U.S. Department of Energy GJBX-410 (81), 2 vol. 
APPENDIX 1. Definition of levels of mineral resource potential and certainty of assessment

Mineral resource potential is defined as the likelihood of the presence of mineral resources in a defined area; it is not a measure of the amount of resources or their profitability.

Mineral resources are concentrations of naturally occurring solid, liquid, or gaseous materials in such form and amount that economic extraction of a commodity from the concentration is currently or potentially feasible.

Low mineral resource potential is assigned to areas where geologic, geochemical, and geophysical characteristics indicate a geologic environment where the existence of resources is unlikely. This level of potential embraces areas of dispersed mineralized rock as well as areas having few or no indications of mineralization. Assignment of low potential requires specific positive knowledge; it is not used as a catchall for areas where adequate data are lacking.

Moderate mineral resource potential is assigned to areas where geologic, geochemical, and geophysical characteristics indicate a geologic environment favorable for resource occurrence, where interpretations of data indicate a reasonable chance for resource accumulation, and where an application of genetic and (or) occurrence models indicates favorable ground.

High mineral resource potential is assigned to areas where geologic, geochemical, and geophysical characteristics indicate a geologic environment favorable for resources, where interpretations of data indicate a high likelihood for resource accumulation, where data support occurrence and (or) genetic models indicating presence of resources, and where evidence indicates that mineral concentration has taken place. Assignment of high resource potential requires positive knowledge that resource-forming processes have been active in at least part of the area; it does not require that occurrences or deposits be identified.

Unknown mineral resource potential is assigned to areas where the level of knowledge is so inadequate that classification of the area as high, moderate, or low would be misleading. The phrase "no mineral resource potential" applies only to a specific resource type in a well-defined area. 'This phrase is not used if there is the slightest possibility of resource occurrence; it is not appropriate as the summary rating for any area.

Expression of the certainty of the mineral resource assessment incorporates a consideration of (1) the adequacy of the geologic, geochemical, geophysical, and resource data base available at the time of the assessment, (2) the adequacy of the occurrence or the genetic model used as the basis for a specific evaluation, and (3) an evaluation of the likelihood that the expected mineral endowment of the area is, or could be, economically extractable.

Levels of certainty of assessment are denoted by letters, A-D (fig. 3).

A. The available data are not adequate to determine the level of mineral resource potential. Level $\mathrm{A}$ is used with an assignment of unknown mineral resource potential.

B. The available data are adequate to suggest the geologic environment and the level of mineral resource potential, but either evidence is insufficient to establish precisely the likelihood of resource occurrence, or occurrence and (or) genetic models are not known well enough for predictive resource assessinent.

C. The available data give a good indication of the geologic environment and the level of mineral resource potential, but additional evidence is needed to establish precisely the likelihood of resource occurrence, the activity of resource-forming processes, or available occurrence and (or) genetic models are minimal for predictive applications.

D. The available data clearly define the geologic environment and the level of mineral resource potential, and indicate the activity of resourceforming processes. Key evidence to interpret the presence or absence of specified types of resources is available, and occurrence and (or) genetic models are adequate for predictive resource assessment.

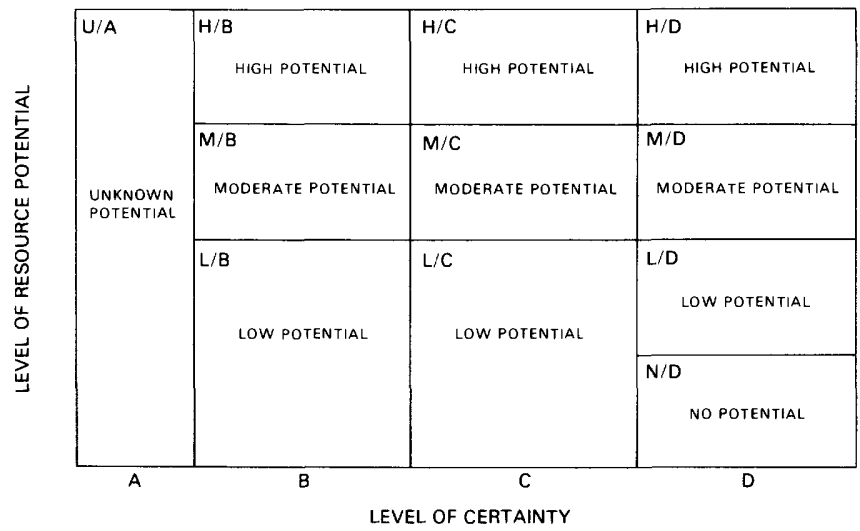

Figure 3. Major elements of mineral resource potential/certainty classification 
GPO 687-049/45013 
